\title{
IMPLEMENTASI PERDAMAIAN (ASH-SHULHU) MELALUI PERMA NOMOR 1 TAHUN 2016 TENTANG PROSEDUR MEDIASI DI PENGADILAN AGAMA KEDIRI TERHADAP PERKARA PERCERAIAN
}

\author{
A.Hasyim Nawawie \\ Institut Agama Islam Negeri Tulungagung \\ Email : ahkamfasih.iainta@gmail.com
}

\begin{abstract}
ABSTRAK
Peradilan Agama telah berfungsi sebagai layaknya lembaga peradilan pada umumnya di bawah Mahkamah Agung Republik Indonesia. Sebagai lembaga peradilan tertinggi di Indonesia Mahkamah Agung dituntut memberikan kepastian hukum dan keadilan bagi pencari keadilan lewat putusan pengadilan di bawahnya (litigasi). Di sisi lain, jalur litigasi masih dianggap lambat, mahal, kaku, tidak mampu memuaskan keinginan kedua belah pihak, bahkan dapat berdampak dendam. Oleh karena itu, alternatif penyelesaian sengketa sebagai jalur non litigasi (perdamaian; win win solution) sangat dibutuhkan, salah satunya adalah mediasi. Terkait dengan prosedur mediasi, Peraturan Mahkamah Agung Nomor.1 Tahun 2008 telah diperbarui yaitu dengan dikeluarkannya Peraturan Mahkamah Agung Nomor 1 Tahun 2016. Penelitian ini merupakan penelitian lapangan (yuridis empiris) di Pengadilan Agama Kediri yang telah menerapkan prosedur mediasi. Teknik pengumpulan data adalah dokumentasi, wawancara dan observasi. Data yang diperoleh dianalisis menggunakan analisis kualitatif untuk menemukan gambaran mengenai penerapan konsep perdamaian (as-sulhu) sejak pemberlakuan Peraturan Mahkamah Agung Nomor 1 Tahun 2016 tentang Prosedur Mediasi di Pengadilan. Fakta yang ditemukan berdasarkan penelitian terbagi menjadi 3 hal yaitu : (1) penerapan konsep perdamaian (As-Sulhu) melalui mediasi di Pengadilan Agama Kediri pada Tahun 2016 telah berlangsung sejak pemberlakuan Peraturan Mahkamah Agung nomor 1 tahun 2016 (Februari - Mei 2016) khususnya terhadap perkara perceraian, (2) pengaruh mediasi di Pengadilan Agama Kediri masih rendah, yaitu $45.3 \%$ dari seluruh perkara yang layak dimediasi, (3) masih terdapat kendala-kendala yang terbagi menjadi empat faktor yaitu dari pihak mediator, para pihak, sarana dan prasarana, serta prosedur mediasi. Peneliti memberikan rekomendasi sebagai berikut: (1) hendaknya Mahkamah Agung sering mengeluarkan aturan teknis mengenai mediasi di pengadilan, (2) rendahnya pengaruh mediasi seharusnya ditindaklanjuti sehingga dapat membantu penekanan terhadap penumpukan perkara, (3) Hendaknya mediator dapat melaksanakan tugas dengan baik, (4)semua pihak baik Pejabat Pengadilan, Hakim, Mediator, Pengacara dan Masyarakat hendaknya turut berperan aktif dan beriktikad baik dalam penyelesaian perkara melalui perdamaian (as-Sulhu) dengan jalur mediasi sehingga penyelesaian perkara lebih mencerminkan keadilan sebagai cita-cita bersama.
\end{abstract}

Kata Kunci: Mediasi, perdamaian, Peraturan Mahkamah Agung Nomor 1 Tahun 2016 


\section{Pendahuluan}

Dalam Pasal 1 butir (1) Undang-Undang Nomor 7 Tahun 1989, disebutkan bahwa Peradilan Agama adalah Peradilan bagi orang-orang yang beragama Islam. Peradilan Agama telah berfungsi sebagai layaknya lembaga peradilan pada umumnya di bawah Mahkamah Agung dengan perkara tertentu yang meliputi perkara perkawinan, waris, wasiat, hibah, wakaf, zakat, infaq, shadaqah dan ekonomi syari'ah.

Jalur litigasi masih dianggap lambat, memerlukan biaya mahal, tidak tanggap (Unresponsive), kaku dan membingungkan, tidak mampu memuaskan keinginan kedua belah pihak, bahkan dapat berdampak emosi dan dendam. Penyelesaian sengketa diluar Pengadilan yang mekanismenya berdasarkan kesepakatan para pihak dengan mengesampingkan penyelesaian sengketa secara litigasi di Pengadilan Alternative Dispute Resolution (ADR) antara lain adalah mediasi. $^{1}$

Mediasi kemudian mendapat perhatian penuh dari kalangan akademisi maupun praktisi hukum di Indonesia setelah diterbitkannya Peraturan Mahkamah Agung (PERMA) Nomor 2 Tahun 2003 tentang Prosedur Mediasi di Pengadilan dan merupakan momentum dimasukkannya proses mediasi ke dalam proses litigasi. Pasal 2 ayat (1) PERMA Nomor 2 Tahun 2003 tentang Prosedur Mediasi di Pengadilan berbunyi :

"Semua perkara perdata yang diajukan ke pengadilan tingkat pertama wajib untuk lebih dahulu diselesaikan melalui perdamaian dengan bantuan mediator."

Pada tanggal 31 Juli 2008 Mahkamah Agung menerbitkan PERMA Nomor 1 Tahun 2008 tentang Prosedur Mediasi di Pengadilan sebagai revisi PERMA Nomor 2 Tahun 2003. Tahun 2016, Mahkamah Agung mengeluarkan Peraturan baru terkait dengan prosedur mediasi yang memperbarui Peraturan Mahkamah

\footnotetext{
${ }^{1}$ Rahmadi Usman, Mediasi di Pengadilan dalam Teori dan Praktek ,Penerbit, Sinar Grafika, Jakarta, Hal. 10
} 
Agung No.1 Tahun 2008 tentang Prosedur Mediasi di Pengadilan, yang telah diperbarui dengan dikeluarkannya Perma No. 1 Tahun 2016. PERMA Nomor 1 Tahun 2016 terdiri dari IX Bab dan 39 pasal. PERMA ini membawa beberapa perubahan penting karena beberapa hal yaitu yang pertama, terkait batas waktu mediasi yang lebih singkat dari 40 hari menjadi 30 hari terhitung sejak penetapan perintah melakukan Mediasi. Kedua, adanya kewajiban bagi para pihak (inpersoon) untuk menghadiri secara langsung pertemuan Mediasi dengan atau tanpa didampingi oleh kuasa hukum, kecuali ada alasan sah tertentu. Ketiga, hal yang paling baru adalah adanya aturan tentang Iktikad Baik dalam proses mediasi dan akibat hukum para pihak yang tidak beriktikad baik dalam proses mediasi.

Lingkungan Peradilan Agama dalam konteks mediasi sangat berbeda dengan lingkungan peradilan lainnya, terutama mengenai kewenangan mengadili. Mediasi sendiri hanya berlaku dalam perkara perdata. Hal ini dapat dilihat dari konsiderasi PERMA Nomor 1 Tahun 2016 yang berbunyi:

"Bahwa Prosedur Mediasi di Pengadilan menjadi bagian hukum secara perdata dapat memperkuat dan mengoptimalkan fungsi lembaga Peradilan dalam penyelesaian sengketa."

Selain dasar hukum tersebut, Pasal 4 PERMA Nomor 1 Tahun 2016 berbunyi :

1) Semua sengketa perdata yang diajukan ke Pengadilan termasuk perkara perlawanan (verzet) atas putusan verstek dan perlawanan pihak berperkara (partij verzet) maupun pihak ketiga (derden verzet) terhadap pelaksanaan putusan yang telah berkekuatan hukum tetap, wajib terlebih dahulu diupayakan penyelesaian melalui Mediasi, kecuali ditentukan lain berdasarkan Peraturan Mahkamah Agung ini.

2) Sengketa yang dikecualikan dari kewajiban penyelesaian melalui Mediasi sebagaimana dimaksud pada ayat (1) meliputi:

a. Sengketa yang pemeriksaannya di persidangan ditentukan tenggang waktu penyelesaiannya meliputi antara lain:

1. Sengketa yang diselesaikan melalui prosedur Pengadilan Niaga;

2. Sengketa yang diselesaikan melalui prosedur Pengadilan Hubungan Industrial; 
3. Keberatan atas putusan Komisi Pengawas Persaingan Usaha;

4. Keberatan atas putusan Badan Penyelesaian Sengketa Konsumen;

5. Permohonan pembatalan putusan arbitrase;

6. Keberatan atas putusan Komisi Informasi;

7. Penyelesaian perselisihan partai politik;

8. Sengketa yang diselesaikan melalui tata cara gugatan sederhana; dan

9. Sengketa lain yang pemeriksaannya di persidangan ditentukan tenggang waktu penyelesaiannya dalam ketentuan peraturan perundang-undangan;

b. Sengketa yang pemeriksaannya dilakukan tanpa hadirnya penggugat atau tergugat yang telah dipanggil secara patut;

c. Gugatan balik (rekonvensi) dan masuknya pihak ketiga dalam suatu perkara (intervensi);

d. Sengketa mengenai pencegahan, penolakan, pembatalan dan pengesahan perkawinan;

e. Sengketa yang diajukan ke Pengadilan setelah diupayakan penyelesaian di luar Pengadilan melalui Mediasi dengan bantuan Mediator bersertifikat yang terdaftar di Pengadilan setempat tetapi dinyatakan tidak berhasil berdasarkan pernyataan yang ditandatangani oleh Para Pihak dan Mediator bersertifikat.

3) Pernyataan ketidakberhasilan Mediasi sebagaimana dimaksud pada ayat (2) huruf e dan salinan sah Sertifikat Mediator dilampirkan dalam surat gugatan.

4) Berdasarkan kesepakatan Para Pihak, sengketa yang dikecualikan kewajiban Mediasi sebagaimana dimaksud pada ayat (2) huruf a, huruf c, dan huruf e tetap dapat diselesaikan melalui Mediasi sukarela pada tahap pemeriksaan perkara dan tingkat upaya hukum.

Tujuan dilakukannya penelitian ini yaitu untuk mengetahui penerapan konsep perdamaian (ash-shulhu) melalui PERMA Nomor 1 Tahun 2016 tentang Prosedur Mediasi terhadap perkara perceraian di Pengadilan Agama Kediri setelah diterbitkannya PERMA tersebut pada Tahun 2016, untuk mengetahui pengaruh mediasi di Pengadilan Agama Kediri terhadap penyelesaian perkara perceraian setelah diterbitkannya PERMA tersebut pada Tahun 2016 dan untuk mengetahui kendala yang dihadapi dalam penerapan konsep ash-shulhu melalui PERMA Nomor 1 Tahun 2016 tentang Prosedur Mediasi terhadap perkara 
perceraian di Pengadilan agama Kediri setelah diterbitkannya PERMA tersebut pada Tahun 2016. Penelitian ini merupakan penelitian lapangan (Yuridis Empiris) terhadap efektifitas norma hukum, bagaimana hukum beroperasi dalam masyarakat. Penelitian ini bersifat deskriptif analitis dan didekati dengan pendekatan historis dan sosiologis.Pendekatan historis dipergunakan ketika membahas tentang sejarah Mediasi di Pengadilan Agama Kediri.

\section{Rumusan Masalah}

Bagaimana Implementasi Perdamaian (Ash-Shulhu) Melalui Peraturan Mahkamah Agung Nomor 1 Tahun 2016 tentang Prosedur Mediasi di Pengadilan Agama Kediri Terhadap Perkara Perceraian.

\section{Tujuan Penelitian}

Untuk mengkaji secara mendalam Implementasi Perdamaian (Ash-Shulhu) Melalui Peraturan Mahkamah Agung Nomor 1 Tahun 2016 tentang Prosedur Mediasi di Pengadilan Agama Kediri Terhadap Perkara Perceraian

\section{Metode Penelitian}

Dalam penelitian ini, digunakan metode penelitian hukum normatif. Sedangkan pendekatan yang digunakan adalah pendekatan perundang-undangan (statute approach), pendekatan kasus (case approach) dan pendekatan komparatif. Jenis bahan hukum yang digunakan ialah bahan hukum primer, sekunder, dan tersier. Teknik memperoleh data pada penelitian ini adalah dengan melakukan studi pustaka (library research). 


\section{Hasil Penelitian dan Pembahasan}

Menurut Sayyid Sabiq, As-Sulhu adalah suatu bentuk akad untuk mengakhiri perselisihan antara dua orang yang berlawanan. Akad tersebut diharapkan dapat menyelesaikan pertikaian secara damai dan saling memaafkan ${ }^{2}$. Lebih lanjut mengenai pengertian perdamaian (As-Sulhu), Pasal 1851 Kitab Undang-undang Hukum Perdata (KUHP) menyatakan :

Di dalam Al-Qur'an dijelaskan panduan praktis untuk mengelola perdamaian, diantaranya : Pertama, perintah untuk saling menjaga dan mempererat tali persaudaraan sebagaimana dijelaskan dalam al-Qur'ān Surah alHujurāt ayat 10 :

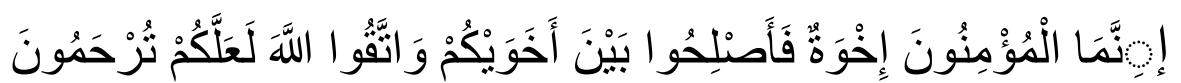

“Orang-orang beriman itu Sesungguhnya bersaudara.sebab itu damaikanlah (perbaikilah hubungan) antara kedua saudaramu itu dan takutlah terhadap Allah, supaya kamu mendapat rahmat".

Kedua, surat An-Nisa' ayat 128 mengenai anjuran perdamaian jika terjadi permasalahan di dalam sebuah rumah tangga:

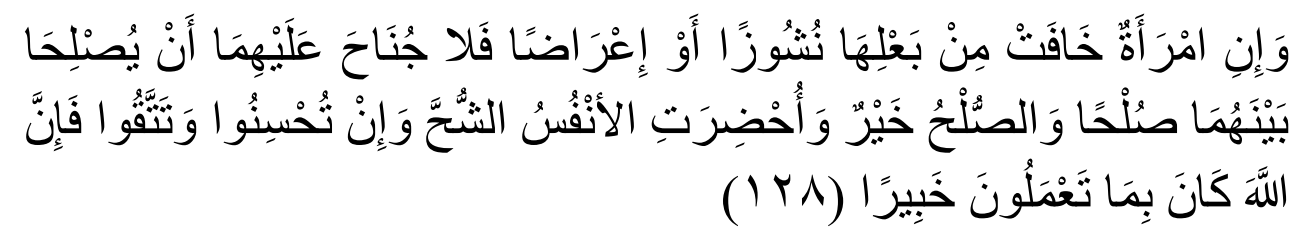

"Dan jika seorang wanita khawatir akan nusyuz atau sikap tidak acuh dari suaminya, maka tidak mengapa bagi keduanya mengadakan perdamaian yang sebenar-benarnya.Dan perdamaian itu lebih baik (bagi mereka) walaupun manusia itu menurut tabiatnya kikir.Dan jika kamu bergaul dengan istrimu secara baik dan memelihara dirimu (dari nusyuz dan sikap tak acuh) maka sesungguhnya Allah maha Mengetahui apa yang kamu kerjakan."

\footnotetext{
${ }^{2}$ Sayyid Sabiq, loc cit . hal.211
} 
Ketiga, larangan untuk mencela, mengolok-olok dan merendahkan orang lain, sebagaimana dalam al-Qur'ān Șurah al-Ḥujurāt ayat 11;

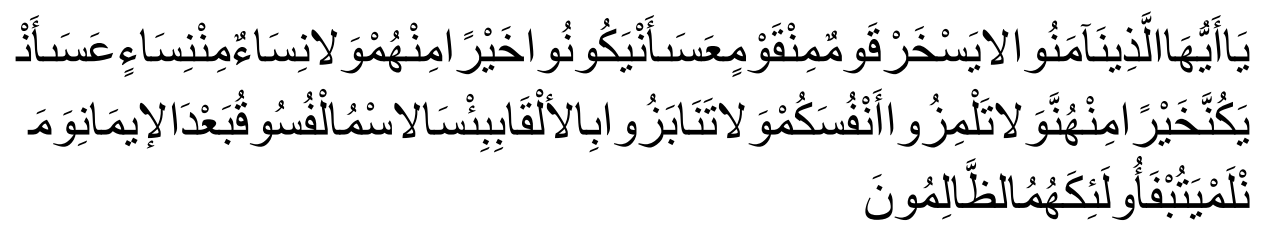

"Hai orang-orang yang beriman, janganlah sekumpulan orang laki-laki merendahkan kumpulan yang lain, boleh Jadi yang ditertawakan itu lebih baik dari mereka. dan jangan pula sekumpulan perempuan merendahkan kumpulan lainnya, boleh Jadi yang direndahkan itu lebih baik. dan janganlah suka mencela dirimu sendiri dan jangan memanggil dengan gelaran yang mengandung ejekan. seburuk-buruk panggilan adalah (panggilan) yang buruk sesudah iman dan Barangsiapa yang tidak bertobat, Maka mereka Itulah orang-orang yang zalim.

Keempat, hadits mengenai perdamaian (As-sulhu) selama tidak bertentangan dengan hal-hal yang berkaitan dengan halal dan haram. Hadits ini diriwayatkan oleh Abu Dawud yang artinya sebagai berikut :

"Perjanjian damai antara orang-orang muslim itu diperbolehkan, kecuali perjanjian menghalalkan yang haram dan mengharamkan yang halal." (HR Abū Dawūd). ${ }^{3}$

Pengertian mediasi juga dapat dijumpai dalam Peraturan Mahkamah Agung Nomor 1 Tahun 2016 yang menyatakan bahwa "mediasi adalah cara penyelesaian sengketa melalui proses perundingan untuk memperoleh kesepakatan Para Pihak dengan dibantu oleh mediator." Dalam berbagai definisi yang ada baik dari istilah hukum maupun definisi dari para ahli hukum, terdapat beberapa unsur mediasi yaitu, Metode alternatif penyelesaian sengketa, Bersifat Non Litigasi, Menggunakan jasa Mediator, Kesepakatan sesuai keinginan para pihak.

Dalam sengketa keluarga misalnya, khusus terkait perkara perceraian, upaya perdamaian diatur dalam Pasal 65 dan Pasal 82 ayat (1) Undang-undang Nomor 7

${ }^{3}$ Sayyid Sabiq. Op cit. hal. 212 
Tahun 1989 tentang Peradilan Agama yang telah diubah dengan Undang-undang Nomor 3 Tahun 2006 dan perubahan kedua dengan Undang-undang Nomor 50 Tahun 2009. Pasal 65 menyebutkan: "Perceraian hanya dapat dilakukan di depan sidang Pengadilan setelah Pengadilan yang bersangkutan berusaha dan tidak berhasil mendamaikan kedua belah pihak." Manakala Pasal 82 ayat (1) menyebutkan: "Pada sidang pertama pemeriksaan gugatan perceraian, Hakim berusaha mendamaikan kedua belah pihak".

Upaya perdamaian tidak hanya diusahakan hakim pada saat permulaan sidang, tetapi juga pada setiap proses pemeriksaan perkara, termuat dalam Undang-Undang Nomor 50 Tahun 2009 "Selama perkara belum diputuskan, usaha mendamaikan dapat dilakukan pada setiap pemeriksaan”.

Dalam PERMA Nomor 1 Tahun 2016, Mediator adalah Hakim atau pihak lain yang memiliki Sertifikat Mediator sebagai pihak netral yang membantu Para Pihak dalam proses perundingan guna mencari berbagai kemungkinan penyelesaian sengketa tanpa menggunakan cara memutus atau memaksakan sebuah penyelesaian

Setiap mediator pada asasnya wajib memiliki sertifikat mediator yang diperoleh dari Mahkamah Agung. Namun Jika dalam wilayah sebuah Pengadilan mediator bersertifikat, hakim di lingkungan Pengadilan yang bersangkutan berwenang menjalankan fungsi mediator.

Mediasi dapat dilakukan jika pada hari sidang yang telah ditentukan yang dihadiri kedua belah pihak. Setelah menjelaskan prosedur mediasi, Majelis Hakim memberi kesempatan kepada para pihak untuk menentukan mediator melalui daftar mediator yang telah disediakan. Namun apabila para pihak pada hari itu juga, atau paling lama dua hari berikutnya tidak mencapai kesepakatan dalam memilih mediator, Majelis Hakim segera menunjuk mediator dan menunda persidangan untuk mediasi.

Dalam waktu paling lama 5 (lima) hari kerja setelah para pihak menunjuk mediator yang disepakati atau yang ditunjuk oleh Majelis Hakim, 
masing-masing pihak dapat menyerahkan resume perkara kepada satu sama lain dan kepada mediator. Proses mediasi berlangsung paling lama 30 (tiga puluh) hari kerja sejak penunjukan mediator, namun atas dasar kesepakatan para pihak, jangka waktu mediasi dapat diperpanjang paling lama 30 (tiga puluh) hari kerja terhitung sejak berakhir jangka waktu.

Dalam membantu merumuskan Kesepakatan Perdamaian, Mediator wajib memastikan Kesepakatan Perdamaian tidak memuat ketentuan yang :

5.1. Bertentangan dengan hukum, ketertiban umum, dan/atau kesusilaan;

5.2. Merugikan pihak ketiga; atau

\subsection{Tidak dapat dilaksanakan.}

Jika dalam proses mediasi diwakili oleh kuasa hukum, penandatanganan Kesepakatan Perdamaian hanya dapat dilakukan apabila terdapat pernyataan para pihak secara tertulis yang memuat persetujuan atas kesepakatan yang dicapai. Para Pihak melalui Mediator dapat mengajukan Kesepakatan Perdamaian kepada Hakim Pemeriksa Perkara agar dikuatkan dalam Akta Perdamaian. Jika Para Pihak tidak menghendaki Kesepakatan Perdamaian dikuatkan dalam Akta Perdamaian, Kesepakatan Perdamaian wajib memuat pencabutan gugatan. Mediator wajib melaporkan secara tertulis keberhasilan Mediasi kepada Hakim Pemeriksa Perkara dengan melampirkan Kesepakatan Perdamaian.

Setelah menerima Kesepakatan Perdamaian, Hakim Pemeriksa Perkara segera mempelajari dan menelitinya dalam waktu paling lama 2 (dua) hari. Dalam hal Kesepakatan Perdamaian yang diminta dikuatkan dalam Akta Perdamaian belum memenuhi ketentuan, Hakim Pemeriksa Perkara wajib mengembalikan Kesepakatan Perdamaian kepada Mediator dan Para Pihak disertai petunjuk tentang hal yang harus diperbaiki. Setelah mengadakan pertemuan dengan Para Pihak, Mediator wajib mengajukan kembali Kesepakatan Perdamaian yang telah diperbaiki kepada Hakim Pemeriksa Perkara paling lama 7 (tujuh) hari terhitung sejak tanggal penerimaan petunjuk perbaikan. Paling lama 3 (tiga) hari setelah menerima Kesepakatan Perdamaian yang telah 
memenuhi ketentuan, Hakim Pemeriksa Perkara menerbitkan penetapan hari sidang untuk membacakan Akta Perdamaian. Kesepakatan Perdamaian yang dikuatkan dengan Akta Perdamaian tunduk pada ketentuan keterbukaan informasi di Pengadilan.

Dalam Perma ini, apabila hal proses Mediasi mencapai kesepakatan antara penggugat dan sebagian pihak tergugat, penggugat mengubah gugatan dengan tidak lagi mengajukan pihak tergugat yang tidak mencapai kesepakatan sebagai pihak lawan. Kesepakatan Perdamaian Sebagian antara pihak, dijelaskan dalam Perma Bagian Kelima Pasal 29, 30 dan 31, yang dibuat dan ditandatangani oleh penggugat dengan sebagian pihak tergugat yang mencapai kesepakatan dan Mediator.

Namun sebelum para pihak menandatangani kesepakatan, mediator memeriksa materi kesepakatan perdamaian untuk menghindari ada kesepakatan yang bertentangan dengan ketentuan hukum yang berlaku atau yang tidak dapat dilaksanakan, tidak menghasilkan kesepakatan paling lama 30 (tiga puluh) hari berikut perpanjangannya, atau yang memuat iktikad yang tidak baik. Dalam hal tersebut

Bahwa jika para pihak tidak mampu menghasilkan kesepakatan, atau dalam hal Mediasi Tidak Berhasil atau tidak dapat dilaksanakan, mediator wajlb menyatakan secara tertulis bahwa proses mediasi tidak berhasil mencapai kesepakatan dan tidak dapat dilaksanakan serta memberitahukannya secara tertulis kepadaHakim Pemeriksa Perkara. Setelah menerima pemberitahuan tersebut, hakim Pemeriksa Perkara segera menerbitkan penetapan untuk melanjutkan pemeriksaan perkara sesuai ketentuan hukum acara yang berlaku.

Para pihak, atas dasar kesepakatan mereka, dapat menempuh upaya perdamaian terhadap perkara yang sedang dalam proses banding, kasasi, atau peninjauan kembali atau terhadap perkara yang sedang diperiksa pada tingkat banding, kasasi, dan peninjauan kembali sepanjang perkara itu belum diputus. Kesepakatan para pihak untuk menempuh perdamaian wajib disampaikan secara 
tertulis kepada Ketua Pengadilan untuk segera memberitahukan kepada Ketua Pengadilan Tingkat Banding yang berwenang atau Ketua Mahkamah Agung tentang kehendakpara pihak untuk menempuh perdamaian.

Pengadilan Agama Kediri yang diresmikan pada tanggal 24 Juni 1989 dan dibentuk berdasarkan OrdonatieStaadblat 1882-152 tentang Peradilan Agama di pulau Jawa dan Madura.

Penerapan upaya perdamaian (as-sulhu) di Pengadilan Agama dilakukan melalui beberapa jalur, di antaranya: ${ }^{4}$

5.1. Nasehat Majelis Hakim

\subsection{Mediasi}

\subsection{Hakam}

Penyelesaian sengketa pada proses damai diatur dalam HIR (Het Herziene Indonesich Reglement, Staatblad 1941: 44), R.Bg (Rechtsreglement Buitengewesten, Staatsblad, 1927: 27) dan Rv (Reglement op de Rechtsvordering, Staatsblad 1874: 52). Disebutkan bahwa hakim atau majelis hakim akan mengusahakan perdamaian sebelum perkara mereka diputuskan. Ketentuan pasal ini adalah :

5.1. Jika pada hari yang ditentukan, kedua belah pihak datang, maka pengadilan negeri dengan pertolongan ketua mencoba akan mendamaikan mereka.

5.2. Jika perdamaian yang demikian itu dapat dicapai, maka pada waktu bersidang, diperbuat sebuah surat akta tentang itu, dalam mana kedua belah pihak dihukum akan menepati perjanjian yang diperbuat itu, surat mana akan berkekuatan dan akan dijalankan sebagai keputusan biasa.

5.3. Keputusan yang sedemikian itu tidak dapat diizinkan banding.

\footnotetext{
${ }^{4}$ Wawancara:.Zaenal Arifin, salah satu Mediator Pengadilan Agama Kediri, tanggal 05 April 2016.
} 
5.4. Jika pada waktu mencoba akan mendamaikan kedua belah pihak, perlu dipakai juru bahasa, maka peraturan pasal yang berikut dituruti untuk itu. ${ }^{5}$

Instrumen yang paling penting dalam menjalankan mediasi di pengadilan agama adalah hakim. Pengadilan Agama Kediri hingga Mei 2016, hanya ada 4 orang hakim, termasuk di dalamnya Ketua dan Wakil Ketua Pengadilan Agama Kediri. ${ }^{6}$ Dari empat hakim tersebut, semuanya telah mempunyai sertifikat mediator dari Mahkamah Agung RI, yaitu:

5.1. Drs. M. Zaenal Arifin, $M H$.

5.2. Drs. H. Imam Syafi'i, SH., MH.

5.3. Drs. Moh Muchsin.

\subsection{Moehamad Fathnan, M.HI}

Tahapan pelaksanaan mediasi di Pengadilan Agama Kediri adalah sebagai berikut: ${ }^{7}$

5.1. Pada persidangan pertama yang dihadiri kedua belah pihak, Majelis Hakim memeriksa identitas para pihak dan berusaha menasehati agar menyelesaikan sengketa melalui perdamaian. ${ }^{8}$ Jika berhasil, pihak Penggugat/Pemohon mencabut perkara yang bersangkutan. Dalam hal pihak yang tidak hadir pada sidang pertama, dapat dilakukan pemanggilan yang sah dan patut satu kali lagi sesuai dengan praktik hukum acara sebagaimana dalam pasal 17 ayat (3) Perma No.1 Tahun 2016.

5.2. Jika tidak berhasil, maka Majelis Hakim menjelaskan mengenai ketentuan Peraturan Mahkamah Agung Nomor 1 tahun 2016 tentang

\footnotetext{
${ }^{5}$ Ibid.Pasal 130 HIR jo. 154 Rbg jo. 13 Rv.

${ }^{6}$ Wawancara;Moh Ali., Kasubag KepegawaianPengadilan Agama Kediri, tanggal 04April2016.

${ }^{7}$ Wawancara; Moh. Muchsin, Hakim Mediator Pengadilan Agama Kediri, tanggal 05April 2016.

${ }^{8}$ Pasal 82 ayat (1) UU No. 07 tahun 1989 tentang Peradilan Agama.
} 
prosedur mediasi sebagaimana dimaksud dalam Pasal 17 ayat (7) Perma Nomor 1 Tahun 2016 di pengadilan dan menyerahkan formulir .

5.3. Sesuai dengan Pasal 3 Perma No.1 Tahun 2016, "Hakim Pemeriksa Perkara dalam pertimbangan putusan wajib menyebutkan bahwa perkara telah diupayakan perdamaian melalui Mediasi dengan menyebutkan nama Mediator."9

5.4. Sesuai dengan Pasal 20ayat (5) Perma No.1 Tahun 2016, "Jika para pihak telah memilih mediator sebagaimana dimaksud ayat (1) atau ketua majelis hakim pemeriksa perkara menunjuk Mediator sebagaimana dimaksud pada ayat (3) atau ayat (4), ketua majelis hakim pemeriksa perkara menerbitkan penetapan yang memuat perintah untuk melakukan mediasi dan menunjuk mediator." ${ }^{10}$ Fungsi Mediator dapat dilaksanakan oleh mediator Hakim, Pegawai Pengadilan yang bersertifikat mediator, atau Mediator nonhakim dan bukan pegawai Pengadilan.

5.5. Sebagaimana dalam Pasal 17 Perma No.1 Tahun 2016 “ Hakim Pemeriksa wajib menunda proses persidangan untuk memberikan kesempatan para Pihak menempuh mediasi."11,

5.6. Mediator yang telah ditunjuk menyusun jadwal mediasi bersama Para pihak Setelah jadwal tersusun, mediasi tetap diselenggarakan setelah pemanggilan para pihak dilakukan secara sah dan patut sebagaimana dalam Perma No.1 Tahun 2016pasal 21 ayat (2).

5.7. Sesuai dengan Pasal 20 ayat (1)Perma No.1 Tahun 2016, "Dalam waktu paling lama 5 (lima) hari terhitung sejak penetapan sebagaimana dimaksud dalam Pasal 20 ayat (5), para pihak dapat menyerahkan Resume Perkara kepada pihak lain dan Mediator.” )

\footnotetext{
${ }^{9}$ Pasal 3 ayat 2 Perma No. 1 Tahun 2016 mengenai Pedoman Mediasi di Pengadilan

${ }^{10}$ Pasal 3 ayat 2 Perma No.1 Tahun 2016 mengenai Pedoman Mediasi di Pengadilan

${ }^{11}$ Pasal 20 ayat 5 Perma No.1 Tahun 2016 mengenai Batas waktu pemilihan Mediator
} 
5.8. Mediator menyerahkan laporan hasil mediasi kepada Ketua Majelis serta pernyataan pihak secara tertulis yang ditandatangani oleh para pihak dan mediator.

5.9. Mejelis Hakim melanjutkan pemeriksaan perkara sebagaimana hukum acara yang berlaku.

Berdasarkan data di atas dapat diketahui bahwa tidak semua perkara dapat dimediasi. Perkara-perkara yang dapat dimediasi tidak seluruhnya berhasil mencapai kesepakatan, dikarenakan adanya faktor penghambat maupun pendukung yang sangat berpengaruh terhadap keberhasilan/kegagalan mediasi. ${ }^{12}$

5.1. Faktor Penghambat Proses Mediasi di Pengadilan Agama Kediri yaitu:

5.1.1. Jangka waktu mediasi

5.1.2. Kehadiran para pihak

5.1.3. Jumlah Mediator dan Jumlah Hakim yang terbatas

5.1.4. Iktikad baik para pihak

5.1.5. Dukungan Majelis Hakim Pemeriksa Perkara

5.1.6. Dukungan pengacara

5.1.7. Ruangan mediasi

\subsection{Faktor Pendukung Keberhasilan Proses Mediasi}

Pimpinan Mahkamah Agung, melakukan upaya untuk menggalakkan Mediasi secara terstruktur dan berkelanjutan, hal ini dapat dilihat dari materimateri mediasi diberikan pada setiap pelatihan: Diklat Calon Hakim, Diklat Panitera / Panitera Pengganti, Diklat Hakim berkelanjutan serta Diklat Calon Pimpinan Pengadilan Umum dan Agama pada tingkat pertama maupun banding. ${ }^{13}$

Usaha-usaha yang dilakukan oleh pimpinan Pengadilan Agama Kediri untuk mendukung keberhasilan mediasi telah dilakukan secara berkala, dengan mengirimkan Hakim untuk mengikuti pelatihan mediasi. Pada bulan Mei 2015

\footnotetext{
${ }^{12}$ Wawancara; Moh Muchsin, Mediator Hakim Pengadilan Agama Kediri, tanggal 05 April
} 2016.

${ }^{13}$ Ahmad Kamil, Makalah Seminar Nasional: Mediasi dan Bantuan Hukum di Lingkungan Peradilan Agama “Agenda dan Problematika", Universitas Islam Indonesia: Sabtu, 21 Januari 2012, 
Pengadilan Agama Kediri telah mengutus salah satu Pegawaiyang menjabat sebagai Panitera, bernama Drs. H.DULLOH, S.H., M.H. untuk mengikuti pelatihan dan sertifikasi mediasi di Diklat Pengadilan Tinggi Agama Surabaya di Surabaya, Jawa Timur. ${ }^{14}$

Tidak dilaksanakannya mediasi dalam sebuah pemeriksaan perkara dapat menyebabkan putusan perkara yang bersangkutan batal demi hukum. Majelis Hakim yang bersangkutan berkewajiban menjelaskan kepada para pihak untuk menempuh mediasi. Jika dalam perkara tersebut terdapat pihak turut Tergugat, maka ketidakhadiran pihak turut Tergugat tidak menghalangi mediasi.Para pihak memiliki hak untuk memilih mediator yang mereka kehendaki bersama dalam waktu paling lama tiga hari kerja, sejak hari persidangan yang dihadiri lengkap oleh kedua belah pihak. ${ }^{15}$

Dari indikasi tersebut selanjutnya untuk mengetahui prosentase perkara yang berhasil di mediasi dalam satu tahun dapat menggunakan rumusan sebagai berikut:

\section{Jumlah perkara yang dicabut Jumlah perkara yang diputus}

Pada periode Oktober 2015 Januari 2016, perkara yang dinyatakan layak untuk dilakukan mediasi sebanyak 50 perkara, dari jumlah yang layak di mediasi tersebut, yang berhasil mencapai 15 perkara.

Berdasarkan rumusan mengenai prosentase sebagai tolak ukur keberhasilan mediasi di Pengadilan Agama Kediri, yang berhasil di mediasi pada periode Oktober 2015- Januari 2016 adalah sebagai berikut:

$$
\frac{15}{50} \times 100 \%=30 \%
$$

\footnotetext{
${ }^{14}$ Wawancara: Drs. M Zaenal Arifin, S.H. M.H.,, Ketua Pengadilan Agama Kediri, tanggal 05 April 2016.

${ }^{15}$ Direktorat Badilag MARI (2010), Pedoman Pelaksanaan Tugas dan Administrasi Peradilan Agama (Buku II edisi 2010), Jakarta, hlm. 82-85.
} 
Sedangkan pada periode selanjutnya, dari jumlah perkara perceraian yang didaftarkan sebanyak 206 perkara di Pengadilan Agama Kediri Februari - Mei tahun 2016, perkara yang dinyatakan layak untuk dilakukan mediasi sebanyak 53 perkara, dari jumlah yang layak di mediasi tersebut, yang berhasil mencapai 24 perkara.

Berdasarkan rumusan mengenai prosentase sebagai tolak ukur keberhasilan mediasi di Pengadilan Agama Kediri, yang berhasil di mediasi pada periode Februari - Mei tahun 2016 sebagai berikut:

$$
\frac{24}{53} \times 100 \%=45,3 \%
$$

Dapat diketahui bahwa perkara yang berhasil di mediasi pada Pengadilan Agama Kediri selama Oktober 2015 - Januari 2016 adalah sebesar 30\%, sedangkan periode Februari - Mei tahun 2016 adalah sebesar 45.3 \%, dari semua perkara yang layak untuk dimediasi. Dari hasil tersebut, tampak bahwa tingkat keberhasilan mediasi mengalami peningkatan yaitu dari 30\% menjadi 45,3\%. Terdapat berbagai macam kendala dan permasalahan yang dihadapi. Kendalakendala tersebut antara lain berasal dari :

5.1. Para Pihak

5.1.1. Ketidakhadiran para pihak.

5.1.2. Kurangnya iktikad baik dari para pihak, sebagaimana dijelaskan pada perma.

5.1.3. Kurangnya pemanfaatan media komunikasi audio visual,apabila pihak berhalangan hadir dalam proses mediasi.

5.1.4. Keinginan Kuat dari Para Pihak Untuk Bercerai.

\subsection{Mediator}

5.2.1. Jumlah Mediator yang terbatas, sehingga beban kerja hakim yang juga bertugas sebagai mediator semakin berat.

5.2.2. Tidak dipahaminya tugas dan fungsi mediator dengan baik. 
5.3. Sarana dan Prasarana.

\subsection{Prosedur Mediasi}

5.4.1. Ada majelis hakim yang menjelaskan terlebih dahulu mengenai prosedur mediasi, dan

5.4.2. Ada pula majelis hakim yang langsung memerintahkan pihak untuk mediasi, tanpa menjelaskan secara jelas mengenai prosedur mediasi.

Mediasi dalam perkara perceraian, jangka waktu mediasi yang diberikan mejelis hakim kepada mediator juga perlu mendapatkan perhatian serius. Sebagaimana data yang penulis dapatkan, untuk keperluan mediasi majelis hakim menunda persidangan selama dua minggu (14 hari). Padahal Peraturan Mahkamah Agung memberikan waktu paling lama 30 hari kerja terhitung setelah penetapan perintah untuk melakukan mediasi, yaitu sebagai berikut :

"Proses Mediasi berlangsung paling lama 30 (tiga puluh) hari terhitung sejak penetapan perintah melakukan Mediasi."

Bahkan dapat diajukan juga perpanjangan jangka waktu pelaksanaan mediasi disertai dengan alasannya :

"Atas dasar kesepakatan Para Pihak, jangka waktu Mediasi dapat diperpanjang paling lama 30 (tiga puluh) hari terhitung sejak berakhir jangka waktu sebagaimana dimaksud pada ayat (2). “17

"Mediator atas permintaan Para Pihak mengajukan permohonan perpanjangan jangka waktu Mediasi sebagaimana dimaksud pada ayat (3) kepada Hakim Pemeriksa Perkara disertai dengan alasannya." 18

${ }^{16}$ Pasal 24 Ayat (2) Peraturan Mahkamah Agung Nomor 1 Tahun 2016 tentang Jangka waktu proses Mediasi.

${ }^{17}$ Pasal 24 Ayat (3) Peraturan Mahkamah Agung Nomor 1 Tahun 2016 tentang Jangka waktu proses Mediasi.

${ }^{18}$ Pasal 24 Ayat (4) Peraturan Mahkamah Agung Nomor 1 Tahun 2016 tentang Jangka waktu proses Mediasi. 
Keterpisahan mediasi dengan proses litigasi melalui persidangan juga perlu ditinjau ulang relevansinya terhadap keberhasilan mediasi. Pasal 19 Ayat (1) Peraturan Mahkamah Agung Nomor 1 Tahun 2016 menjelaskan bahwa jika para pihak gagal mencapai kesepakatan, pernyataan dan pengakuan para pihak dalam prosesmediasi tidak dapat digunakan sebagai alat bukti dalam proses persidangan perkara yangbersangkutan atau perkara lain.

Perdamaian (as-sulhu) menjadi puncak dari segala hukum sebagaimana ungkapan Wakil Ketua Mahkamah Agung Republik Indonesia bidang non yudisial:

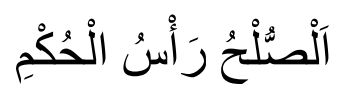

"Perdamaian adalah puncak dari segala hukum."19

Pada kesempatan berbeda, Sekretaris Mahkamah Agung Republik Indonesia berpendapat mengenai konsep perdamaian sebagai berikut:

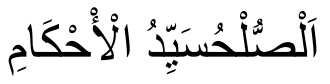

"Perdamaian adalah puncak dari hukum-hukum."20

Pengaruh mediasi di Pengadilan Agama Kediri masih terbilang rendah (45.3\%) dari jumlah perkara yang layak dimediasi). Harus diakui, penerapan Peraturan Mahkamah Agung Nomor 1 tahun 2016 baru berjalan enam bulan sehingga masih terdapat kelemahan-kelemahan yang mengakibatkan kesepakatan perdamaian dalam mediasi belum mencapai prosentase yang signifikan.

Upaya Pimpinan Mahkamah Agung dalam melakukan dan menggalakkan mediasi secara terstruktur dan berkelanjutan dengan memberi materi-materi mediasi pada setiap pelatihan mediasi, diklat calon hakim, panitera / panitera

${ }^{19}$ M. Fauzan, Asas-asas Hukum Acara Perdata, Makalah disampaikan dalam diklat II pembekalan Calon Hakim Peradilan Agama di Megamendung, Bogor pada tanggal 22 Oktober 2012.

${ }^{20}$ M. Rum Nessa, Reformasi Peradilan Dalam Rangka Reformasi Birokrasi, Makalah disampaikan dalam diklat II pembekalan Calon Hakim Peradilan Agama di Megamendung, Bogor pada tanggal 06 Oktober 2012. 
pengganti berkelanjutan serta diharapkan dapat berjalan secara terus menerus dan tentunya bagi para mediator agar dapat lebih berkualitas dan memiliki pemahaman yang lebih mengenai Perma Nomor 1 Tahun 2016.

\section{Kesimpulan}

6.1. Penerapan perdamaian (as-sulhu) melalui PERMA Nomor 1 Tahun 2016 tentang Prosedur Mediasi di Pengadilan Agama Kediri pada Tahun 2016 setelah berlakunya Perma Mediasi baru mengalami perkembangan yang signifikan kerana konsep perdamaian (as-sulhu) telah diintegrasikan kedalam proses peradilan dan memiliki kepastian hukum.

6.2. Pengaruh PERMA Nomor 1 Tahun 2016 yang masih terbilang baru karena masih berjalan selama kurang lebih 4 Bulan, cukup baik, karena bisa memperoleh tingkat keberhasilan 45,3\% jika dibandingkan dengan sebelum diterapkannya perma baru dalam 4 bulan terakhir yaitu sebesar 30\%.Namun demikian,mediasi di Pengadilan Agama Kediri terhadap penyelesaian perkara pada Tahun 2016 dirasa masih perlu ditingkatkan lagi prosentase keberhasilannya dikarenakan masih ditemukan kendala-kendala yang menyebabkan mediasi belum mencapai kesepakatan.

6.3. Kendala yang dihadapi dalam penerapan perdamaian (as-sulhu) melalui PERMA Nomor 1 Tahun 2016 tentang Prosedur Mediasi di Pengadilan Agama Kediri pada Tahun 2016 setelah diterapkannya perma mediasi baru yaitu :

6.3.1. ketidakhadiran para pihak,

6.3.2. Kurangnya iktikad baik dari para pihak, sebagaimana dijelaskan pada perma.

6.3.3. Kurangnya pemanfaatan media komunikasi audio visual,apabila pihak berhalangan hadir dalam proses mediasi.

6.3.4. Keinginan dari Para Pihak Untuk Bercerai.

6.3.5. Jumlah Mediator yang terbatas 
6.3.6. Tidakdipahaminyatugasdanfungsi mediator denganbaik.

6.3.7. Sarana dan Prasarana.

6.3.8. Terdapat perbedaan persepsi mengenai prosedur mediasi baik diantara mediator, maupun hakim pemeriksa perkara. 


\section{DAFTAR PUSTAKA}

\section{Peraturan Perundang-undangan}

Undang-Undang Dasar Negara Republik Indonesia Tahun 1945

Kitab Undang-Undang Hukum Perdata

Kompilasi Hukum Islam

Undang-Undang Republik Indonesia Nomor 48 Tahun 2009 tentang Kekuasaan Kehakiman

Undang-Undang Republik Indonesia Nomor 4 Tahun 2004 tentang pokok-pokok Kekuasaan Kehakiman

Undang-Undang Republik Nomor 14 tahun 1970 tentang ketentuan- ketentuan Pokok Kekuasaan Kehakiman

Undang-undang Nomor. 08 tahun 2004 tentang Perubahan pertama Atas Undangundang Nomor 2 Tahun 1986 Tentang Peradilan Umum.

Undang-undang Nomor. 49 tahun 2009 tentang Perubahan kedua Atas Undangundang Nomor 2 Tahun 1986 Tentang Peradilan Umum.

Undang-undang Nomor 7 Tahun 1989 tentang Peradilan Agama.

Undang-undang Nomor 3 Tahun 2006 tentang Peradilan Agama.

Undang-undang Nomor 50 Tahun 2009 tentang Peradilan Agama.

Undang-undang Nomor 30 Tahun 1999 tentang Arbitrase dan Alternatif Penyelesaian Sengketa

Peraturan Permerintah Nomor 9 Tahun 1975 tentang Pelaksanaan Undang-undang Nomor 1 Tahun 1974 tentang Perkawinan.

Peraturan Mahkamah Agung RI Nomor 1 Tahun 2016 tentang Prosedur Mediasi di Pengadilan

Surat Edaran Mahkamah Agung (Sema) RI Nomor 1 Tahun 2002 Tentang Pemberdayaan Pengadilan Tingkat Pertama Menetapkan Lembaga Damai.

\section{Literatur Ilmiah}

Abbas, Syahrizal. (2009) Mediasi, Kencana Prenada Media Group, Jakarta.

Ali, Achmad dan Wiwie Heryani. (2012) Sosiologi Hukum: Kajian Empiris Terhadap Pengadilan, Kencana, Jakarta.

Asmu'i ,Imam.(2015). Implementasi Perdamaian (As-Sulhu) Melalui Perma Nomor. 1 Tahun 2008 Tentang Prosedur Mediasi Di Pengadilan (Studi Di Pengadilan Agama Kabupaten Kediri), Uniska, Kediri.

Zainuddin Ali. (2011), Metode Penelitian Hukum, Sinar Grafika, Jakarta, cet. ketiga, hlm. 224

Arto, H.A. Mukti. (2011) Praktek Perkara Perdata Pada Pengadilan Agama, Pustaka Pelajar, Yogyakarta.

Depag RI, Al-Qur'an dan Terjemahnya, Jakarta.

Dep. Pendidikan dan Kebudayaan, Kamus Besar Bahasa Indonesia, Edisi kedua, Balai Pustaka, Jakarta. 
Harahap, Yahya. (2005) Kedudukan Kewenangan dan Acara Peradilan Agama, Sinar Grafika, Jakarta.

Harahap, Yahya, (2010) Hukum Acara Perdata, Sinar Grafika, Jakarta.

Ka'bah, Rifyal. (2004) Penegakan Syari'at Islam di Indonesia, Khoirul Bayan, Jakarta.

Kamil, Ahmad. (2012) Filsafat Kebebasan Hakim, Kencana, Jakarta.

Komisi Yudisial RI. (2011) Penerapan dan Penemuan Hukum dalam Putusan Hakim, Sekjen Komisi Yudisial RI, Jakarta.

Lev, Daniel S. (1986) Peradilan Agama Islam di Indonesia, terj. Zaini Ahmad Noeh, Intermasa, Jakarta.

Mahkamah Agung RI, Japan International coorporation agency (JICA) dan Indonesian Institute for Conflict Transformation (IICT). (2008): Buku Komentar Peraturan Mahkamah Agung RI Nomor 1 Tahun 2008 tentang pelaksanaan mediasi di pengadilan, softcopy, tanpat penerbit.

Manan, Bagir. (2007) Peradilan Agama Dalam Perspektif Ketua Mahkamah Agung, Direktorat Jendral Badan Peradilan Agama, Jakarta.

Mannan, Abdul. (2013), Aspek-Aspek Pengubah Hukum, Kencana, Jakarta.

Mannan, Abdul. (2012) Aneka Masalah Hukum Perdata Islam di Indonesia, Kencana, Jakarta.

Mannan, Abdul. (2012) Penerapan Hukum Acara Perdata di Lingkungan Peradilan Agama, Kencana, Jakarta.

Mannan, Abdul. (2007) Etika Hakim Dalam PenyelenggaraanPeradilan, Kencana Jakarta.

Margono, Suyud. (2009) Undang-undang Nomor 30 Tahun 1999 Tentang Arbitrase dan Alternatif Penyelesaian Sengketa, Novindo Pustaka Mandiri, Jakarta.

Mariyadi, S.H.,M.H., 2007, Hukum Acara Perdata, Malang, Visipress Media.

Mufid Bisri, Ahmad, Laporan Kegiatan Calon Hakim Magang III, Oktober 2013, Pengadilan Agama Kabupaten Kediri.

Mujahidin, Ahmad. (2012) Pembaharuan Hukum Acara Peradilan Agama, Ghalia Indonesia, Bogor.

Mujahidin, Ahmad, Penerapan Hukum Acara Pengadilan Agama, Makalah disampaikan dalam diklat III pembekalan Calon Hakim Peradilan Agama di Megamendung, Bogor pada tanggal 01 Juli 2013.

Nessa, Rum. Reformasi Peradilan Dalam Rangka Reformasi Birokrasi, Makalah disampaikan dalam diklat II pembekalan Calon Hakim Peradilan Agama di Megamendung, Bogor pada tanggal 06 Oktober 2012.

Nurnaningsih, Mediasi (2012) Alternatif Penyelesaian Sengketa Perdata di Pengadilan, Raja Grafindo Persada, Jakarta.

Prajogo, Soesilo. 2007 Kamus Hukum Internasional dan Indonesia, Wacana Intelektual, Jakarta. 
Pusdiklat Teknis Peradilan. (2012) Bahan Ajar Diklat II Calon Hakim Peradilan Agama PPC Terpadu, Badan Litbang Diklat Kumdil Mahkamah Agung RI, Bogor.

Sabiq, Sayyid. (1990) al-Fiqh al-Sunah, Jilid II, Dar al-Fath, Kairo.

Sofiah, Efi. (2004) "Putusan Perdamaian dan Penerapannya di Pengadilan Agama", dalam Jaih Mubarok (ed.), Peradilan Agama di Indonesia, Pustaka Bani Quraisy, Bandung.

SoemarNomor Gatot. (2006) Arbitrase dan Mediasi di Indonesia, (Jakarta: PT Gramedia Pustaka Utama.

Soesilo. (1995) R. RIB/HIR dengan Penjelasan, Politeia, Bogor.

Soesilo, R. dan Pramudji. (2007) Kitab Undang-Undang Hukum Perdata.

Syam, Marjohan. (2009) Makalah "Hukum Acara dalam Hal Perkara tentang Kebendaan dan Ekonomi Syariah serta Proses Mediasi dalam Litigasi di Indonesia“, disampaikan pada acara penyegaran hakim di Tanjung Balai Karimun, tanpa penerbit.

Andi Syamsu Alam (2012), Urgensi Mediasi Bagi Pencari Keadilan Di Lingkungan Peradilan Agama, Makalah, dimuat di laman Badan Direktorat Jendral Peradilan Agama pada tanggal 04 Januari 2012.

Tim Penyusun. (2010) Pedoman Pelaksanaan Tugas dan Administrasi Peradilan Agama. Buku II edisi 2010, Direktorat Badilag MARI, Jakarta.

Tim Penyusun. (2013) Pedoman Pelaksanaan Tugas dan Administrasi Peradilan Agama. Buku II edisi 2013, Direktorat Badilag MARI, Jakarta.

Tim Penyusun. (1998) Kamus Besar Bahasa Indonesia, Depatemen Pendidikan dan Kebudayaan, Jakarta.

Tim Penyusun. (2008) Buku Pedoman Penulisan Tesis Magister Studi Islam, Jombang, Program Pascasarjana Universitas Darul 'Ulum.

Usman, Rahmadi. (2003) Pilihan Penyelesaian Sengketa di Luar pengadilan, Citra Aditya Bakti, Bandung.

Widagdo, Setiawan . Kamus Hukum, Penerbit PT. Prestasi Pustakaraya, Jakarta.

Witanto,Dy. Hukum Acara Mediasi, Penerbit ALFABETA, Jakarta.

\section{Dokumen :}

Laporan Bulan Oktober 2015 Pengadilan Agama Kediri.

Laporan Bulan Nopember 2015 Pengadilan Agama Kediri.

Laporan Bulan Desember 2015 Pengadilan Agama Kediri.

Laporan Tahunan 2015 Pengadilan Agama Kediri.

Laporan Bulan Januari 2016 Pengadilan Agama Kediri.

Laporan Bulan Pebruari 2016 Pengadilan Agama Kediri.

Laporan Bulan Maret 2016 Pengadilan Agama Kediri.

Laporan Bulan April 2016 Pengadilan Agama Kediri.

Laporan Bulan Mei 2016 Pengadilan Agama Kediri. 


\section{Hasil Wawancara:}

Wawancara, Drs. H. Imam Syafi'i, S.H. M.H, Ketua Majelis pada Pengadilan Agama Kediri, tanggal 05 April 2016.

Wawancara: Drs. M.Zaenal Arifin, S.H., M.H, Hakim Mediator Pengadilan Agama Kediri, tanggal 05 April 2016.

Wawancara; Drs. Moh. Muchsin, Hakim Mediator Pengadilan Agama Kediri, tanggal 05 April 2016.

Wawancara; Moehammad Fathnan, Hakim Mediator Pengadilan Agama Kediri, tanggal 05 April 2016.

Wawancara; Moh. Ali, Staf Kepegawaian Pengadilan Agama Kediri, tanggal 05 April 2016. 